\title{
QUEEN'S
UNIVERSITY
BELFAST
}

\section{Antibody conjugated nanoparticles as a novel form of antibody drug conjugate chemotherapy}

Johnston, M. C., \& Scott, C. J. (2018). Antibody conjugated nanoparticles as a novel form of antibody drug conjugate chemotherapy. Drug Discovery Today: Technologies, 30, 63-69.

https://doi.org/10.1016/j.ddtec.2018.10.003

\section{Published in:}

Drug Discovery Today: Technologies

\section{Document Version:}

Peer reviewed version

\section{Queen's University Belfast - Research Portal:}

Link to publication record in Queen's University Belfast Research Portal

\section{Publisher rights}

Copyright 2018 Elsevier.

This manuscript is distributed under a Creative Commons Attribution-NonCommercial-NoDerivs License

(https://creativecommons.org/licenses/by-nc-nd/4.0/), which permits distribution and reproduction for non-commercial purposes, provided the author and source are cited.

\section{General rights}

Copyright for the publications made accessible via the Queen's University Belfast Research Portal is retained by the author(s) and / or other copyright owners and it is a condition of accessing these publications that users recognise and abide by the legal requirements associated with these rights.

Take down policy

The Research Portal is Queen's institutional repository that provides access to Queen's research output. Every effort has been made to ensure that content in the Research Portal does not infringe any person's rights, or applicable UK laws. If you discover content in the Research Portal that you believe breaches copyright or violates any law, please contact openaccess@qub.ac.uk. 
Title

Antibody conjugated nanoparticles as a novel form of antibody drug conjugate chemotherapy

Authors:

Michael C. Johnston, Christopher J. Scott

Affiliation

Centre for Cancer Research and Cell Biology, Queen's University Belfast, 97 Lisburn Road, Belfast, BT9 7AE. United Kingdom

Corresponding Author

Christopher Scott: c.scott@qub.ac.uk 
Abstract

Antibody conjugated nanoparticles (ACNPs) represent a novel strategy for the development of therapies exploiting antibodies to augment the delivery of chemotherapy payloads.

Following in the footsteps of the success of antibody drug conjugates (ADCs), ACNPs are only now reaching clinical evaluation. In this review we discuss the success of ADCs and explore the opportunities ACNPs offer, such as broad chemotherapy payload selection, high drug to antibody ratios and the ability to finely tailor drug release in comparison to ADCs. The ability of ACNPs to elicit increased avidity due to multivalent effects and the potential to use these modular platforms in immunotherapeutic approaches is also explored. Through addressing challenges that still remain in bringing these complex formulations to the clinic, ACNPs hold obvious potential for the treatment of a wide range of cancers and other diseases where selective targeting of drug agents is essential.

Keywords

Antibody drug conjugate; antibody conjugated nanoparticle; drug to antibody ratio; nanomedicine

Abbreviations

Antibody drug conjugate (ADC), antibody conjugated nanoparticle (ACNP), drug to antibody ratio (DAR), death receptor 5 (DR5), Enhanced Permeability and Retention (EPR), Contract Manufacturing Organisation (CMO)

Acknowledgements

This work was partially funded through a US-Ireland R\&D Partnership grant awarded by HSCNI (STL/5010/14, MRC grant MC_PC_15013) 
1. Introduction

The targeted delivery of chemotherapy to tumours has been a major focus in cancer research since the early $20^{\text {th }}$ century [1]. Antibody drug conjugates (ADCs) are one particular method of enhancing targeting of a drug to the tumour site. Modern ADCs are monoclonal antibodies with highly potent drug molecules covalently linked to them. These 'Trojan horse' therapies are designed to target a tumour-specific receptor and be internalised where they are metabolised in the lysosome, releasing anywhere between 1 to 8 drug molecules which subsequently can elicit their cytotoxic mechanism(s) of action.

ADCs were first evaluated in the late 1950s using antibodies which targeted leukaemia cells and had the anti-cancer drug methotrexate conjugated [2]. The first in human clinical trial involving an ADC was reported in 1983 with encouraging results [3]. However, development of antibodies and ADC drugs stagnated, and it took innovations such as hybridoma fusion and humanisation to overcome the issues of single antibody species production and immunogenicity respectively; opening a pathway for the development of antibody-based drugs.

Currently there are four ADCs that have reached the market. The first to be approved in 2000 was gemtuzumab ozogamicin (Mylotarg®), which was given accelerated approval by the FDA for treatment of acute myeloid leukaemia (AML). Mylotarg® targeted CD33 and carried a DNA fragmenting payload (calicheamicin). However, it was withdrawn from the market after disappointing results from a post-approval trial, becoming the first formulation to be given accelerated approval and then subsequently withdrawn. The disappointing performance of Mylotarg ${ }^{\circledR}$ somewhat subdued industry interest in ADCs, but in 2011 and 2013 respectively, Brentuximab vedotin (Adcetris $\AA$, which targets CD30 positive lymphoma) and trastuzumab emtansine (Kadcyla ${ }^{\circledR}$, which targets HER2 positive breast cancer) were approved; both using anti-tubulin payloads. In 2017 Besponsa ${ }^{\circledR}$ (targeting CD22 positive leukaemias) became the most recent ADC to be approved and like Mylotarg®, uses the 
DNA targeting calicheamicin payload. At this time there are roughly 60 ADCs undergoing clinical trials for various cancers [4].

Another technology with potential in drug delivery are nanoparticle formulations (nanomedicine). Nanomedicine has been much heralded as a formulation-based approach to enhance the bioavailability of drug substances $[5,6]$. Indeed, non-targeted nanoparticles containing current chemotherapies have now reached the market. They are generally liposomes, polymeric or metal nanoparticles. One of the key clinical attributes to these formulations is their ability to reduce the toxicity profiles of the cargo chemotherapeutic thus enhancing the therapeutic window for that agent $[7,8]$. An exemplar of this is Doxil $\circledast$, which is liposomal preparation of doxorubicin and has been on the market for over 20 years [9]. More recently, liposomal irinotecan (Onivyde $\AA$ ) was approved for the treatment of advanced pancreatic cancer [7].

Antibody conjugated nanoparticles (ACNPs) represent a relatively new approach that builds on the success and potential of both ADCs and nanotechnology. Conceptually ACNPs are similar to ADCs in that the antibodies can be used to specifically target diseased cells, thus delivering encapsulated cargo drug (Figure 1\&2). The first targeted nanoparticles appeared in the literature in 1980 and the first to enter clinical trials was in 2011 [10-14]. Herein, we discuss the current status of the concept, its benefits and current bottlenecks. 


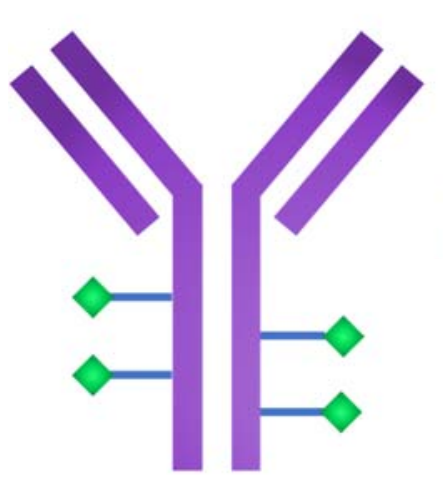

$A D C$

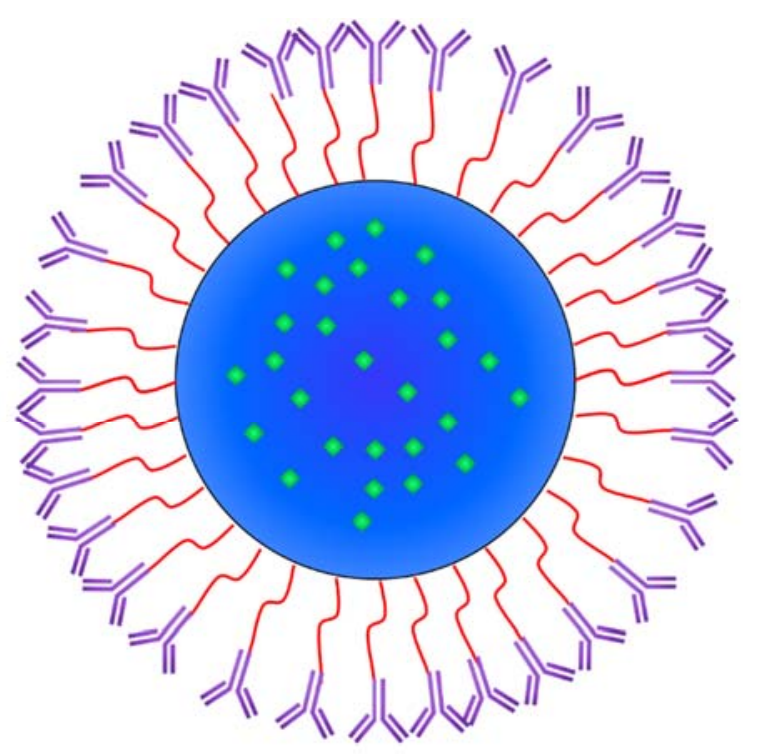

ACNP

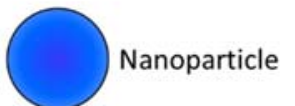

ح PEG linker

Y/ Antibody

Linker

Payload

Figure 1. Schematic representation highlighting the conceptual structure of an ADC and ACNP

\section{Advantages of ACNPs in chemotherapy delivery}

\subsection{Payload selection}

A range of chemotherapies have been evaluated for encapsulation in nanoparticle systems. Whilst there are many various forms of nanoparticles, from liposomes to dendrimers, the choice of nanoparticle carrier is usually dependent on the nature and solubility of the cargo drug to ensure a high drug entrapment. For example, polymeric nanoparticles consisting of commonly employed poly-lactide based polymers are frequently used for the entrapment of hydrophobic agents, whereas liposomes can entrap hydrophobic or hydrophilic drugs in either the phospholipid bilayer of the liposome or its aqueous lumen respectively $[15,16]$. The combination of chemotherapies in nanoparticles has also been explored. This has advantages as it offers the opportunity to overcome pharmacokinetic differences in drug agents to ensure they are delivered at the disease site in the required proportions/ratios to provide synergistic therapeutic effects [17]. 
The diversity of drug agents that can be incorporated into ACNPs offers further development opportunities than can be afforded with standard ADC technologies. Early ADCs used existing standard of care chemotherapies such as methotrexate as their payload and suffered from a lack of potency as a result. Furthermore, it was found that the early linkers used had the potential to reduce payload potency [18-20]. It was soon realised that the payload conjugated to the antibody required much higher potency in order to achieve efficacy. This is because considerably fewer drug molecules were internalised (via receptor mediated endocytosis, which becomes a efficacy-limiting factor) into the target cell when compared to standard chemotherapy [21]. However, with enhanced potency, increased toxicity can be a side effect as was observed with the DNA binding calicheamicin cargo in

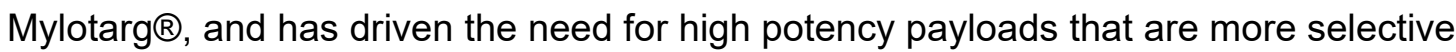
towards actively dividing cancerous cells such as the anti-tubulin agents in Adcetris $₫$ and Kadcyla ${ }^{\circledR}[22]$. Importantly, no direct drug linker is required with ACNPs and therefore this avoids disruption of the payload potency (Figure 1) [23].

\subsection{Drug to antibody ratio (DAR)}

Drug to antibody ratio is an important factor influencing effectiveness of ADCs. It is thought that the optimal DAR for an ADC is approximately only $4: 1$ for the optimal balance between cytotoxicity and acceptable pharmacokinetic profiles [24,25]. It is also important that the DAR is homogenous throughout the formulation population $[26,27]$. ACNPs on the other hand can potentially offer DARs over 100 and consequently when the rate limiting step for drug uptake is receptor copy number on the cell surface, ACNPs may offer an approach to ensure internalisation of much higher concentrations of drug [28]. This higher drug targeting capacity also means that drugs with lower potency than auristatins or mertansines may be successfully employed such as camptothecin derivatives [7]. 


\subsection{Drug release}

With both $A D C$ and ACNP technologies, the selective release of the chemotherapy at the disease site is of paramount importance. In this case of ADCs, this is primarily due to the potential for side effects if healthy tissues are exposed to the highly potent payload. To prevent side effects, ADCs are mostly designed so the drug will only be released upon internalisation into the target cell. This often requires complex linker chemistry, using either cleavable or non-cleavable linkers. Cleavable linkers are usually cleaved in response to a change in the physical environment such as the lowering of $\mathrm{pH}$ in the lysosome or presence of a lysosomal cathepsin-labile motif. With non-cleavable linkers, release of the payload is dependent on the general degradation and metabolism of the ADC in the endo-lysosomal lumen [29].

In ACNPs, as the linker is used to conjugate the antibody to the polymer or lipid, the release of the drug is independent of this. Drug release in these formulations is therefore simply a consequence of both drug diffusion and particle degradation. Whilst almost impossible to prevent some leaching of the drug from nanoparticles unless covalently attached, the use of lower potency chemotherapies as described earlier may mean an acceptable premature release can be tolerated [30]. A strategy that has been explored to maintain drug inside polymeric nanoparticles until uptake, is the use of ion-pairing which serves to hold the drug within the nanoparticle longer through electrostatic interactions, limiting early release and providing a longer therapeutic window once at the disease site [30].

\subsection{Multivalency effects}

The augmenting of receptor clustering and downstream signal transduction, mimicking natural ligand binding is an approach that holds much therapeutic potential, either as an independent agent or in combination with other drugs [31-34]. In the case of ACNPs, antibody conjugation to the surface of the nanoparticle allows for the formulation to exhibit multivalency and can therefore induce hyperclustering of receptors. In the case of death 
receptor 5 (DR5), monovalent targeting antibodies did not show an adequate survival benefit to warrant their use in the clinic. The requirement of Fcy receptor activation is thought to have hindered their efficacy in clinical trials [35-37]. Encouragingly, it has been shown that conjugating an anti-DR5 antibody to the surface of a nanoparticle circumvents the need for Fcy activation and can induce apoptosis in vitro and in vivo [38]. This could potentially offer benefit in the clinic, with the antibody functioning not only as a targeting moiety but also provides therapeutic effects itself. This avidity effect has also been exploited with nanoparticles with other targeting ligands such as carbohydrates [32,39-41].

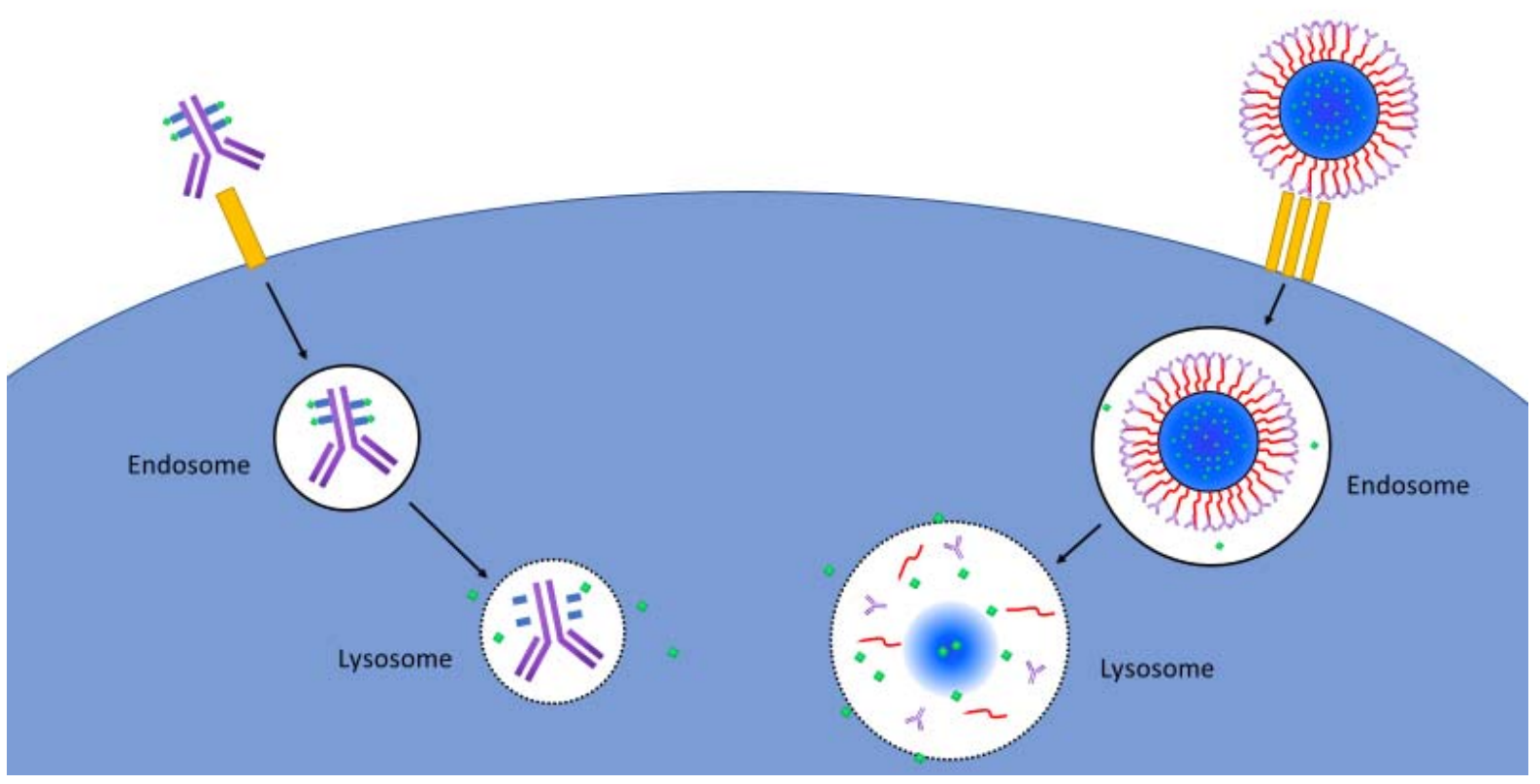

Figure 2. Schematic representation of ADC and ACNP internalisation, breakdown and drug release. (Antibodies illustrated at different scales)

\section{Immunotherapy}

Both passively and actively targeted nanoparticles are now being extensively researched as potential immunotherapies. They are advantageous as immunotherapies tend to require delivery of multiple payloads such as a cancer associated antigen and an adjuvant. Nanoparticles are more suited to the loading of multiple payloads due to the higher DAR they possess in comparison to ADCs. 
One strategy is the targeting of dendritic cells to take advantage their antigen presenting properties. Dendritic cells can then recruit T cells against tumour specific antigen encouraging their maturation into cytotoxic T cells resulting in tumour killing. Passive targeting nanoparticles have been used to deliver both tumour-specific antigens and adjuvants to dendritic cells. It has been demonstrated that altering particle size can increase dendritic cell internalisation when administered subcutaneously $[42,43]$. The use of active targeting has been shown to improve delivery to antigen presenting cells resulting in improved production of cytotoxic T cells and reduced tumour growth in vivo [44]. The dendritic cell targeting formulation Lipovaxin-MM has passed a phase 1 dose escalation study [45].

An alternative approach to targeting antigen presenting cells to stimulate $\mathrm{T}$ cells is to target $\mathrm{T}$ cells directly. ACNPs have also been used to target T cells directly in mouse models which ultimately showed reduced tumour growth and increased survival [46]. While ACNPs have not yet reached clinical trial for their potential use in immunotherapy, the data so far is promising.

\section{Barriers facing ACNPs pathway to the clinic}

There are only a limited number of ACNPs that have reached clinical trials which are summarised in Table 1. None have yet reached phase 3 . While the passively targeted nanoparticle formulations that have reached the market generally cause a more favourable pharmacokinetic profile than their free payload, it does require careful consideration of aspects of nanoparticle size, shape and surface charge. A survey of 117 nanomedicine publications presenting quantitative biodistribution data in cancer models revealed that only a median average of $0.7 \%$ of nanoparticles reach the tumour site in vivo [47]. While it was acknowledged that the formulations on the market or in clinical trial were much higher than this figure, further development is needed to increase the median average across the board. 
The nanomedicine field had over relied on the enhanced permeability and retention (EPR) effect to increase delivery to the tumour; the ability of nanomedicines to seep into tumours due to tumour neovasculature leakiness and reduced interstitial pressure. The FDA approved imaging formulation Ferumoxytolß has been shown to be predictive of nanoparticle accumulation in vivo which could one day give clinicians a useful tool to predict how beneficial nanomedicine could be for a specific patient - a personalised or precision medicine approach [48]. In an effort to increase tumour delivery, methods are now emerging to enhance 'permeability' of the tumour rendering it more susceptible to nanoparticle deposition by selectively targeting the integrity of the tumour specific neovasculature. This has proven to be successful in vivo $[49,50]$. Thus, using approaches like this to overcome reliance on EPR will be essential in order to realise the potential of active targeting on ACNPs. By using the antibody to not only target the tumour but also elicit independent therapeutic effects can only enhance the opportunities provided by the technology [47]. Another key bottleneck at this time is the developability and manufacturability of ACNPs. Routes to synthesis and access to CMOs specialising in the large-scale cGMP manufacturing of ACNPs is an issue that will need to be overcome in order for the technology to become more widely adopted. However, these are issues that have been faced previously with biologics manufacture and with ADC manufacture itself $[51,52]$. Therefore, if therapeutic efficacy of the formulations can be clearly demonstrated, the investment needed by large pharmaceutical organisations in manufacturing to overcome this ‘valley of translational death' will be de-risked and made more compelling. 
Table 1. Antibody targeted nanoparticle formulations that have gone through or are currently undergoing clinical trial adapted from Richards et al. and van der Meel et al. [53,54]

\begin{tabular}{|c|c|c|c|c|c|c|}
\hline Name & Target & Ligand & Type & Payload & Indication & Phase \\
\hline SGT-53 & $\begin{array}{l}\text { Transferrin } \\
\text { receptor }\end{array}$ & $\begin{array}{l}\text { Anti- } \\
\text { transferrin } \\
\text { receptor } \\
\text { ScFv }\end{array}$ & Lipid & P53 DNA & $\begin{array}{l}\text { Recurrent } \\
\text { Glioblastoma }\end{array}$ & II \\
\hline SGT-94 & $\begin{array}{l}\text { Transferrin } \\
\text { receptor }\end{array}$ & $\begin{array}{l}\text { Anti- } \\
\text { transferrin } \\
\text { receptor } \\
\text { ScFv }\end{array}$ & Lipid & RB94 DNA & $\begin{array}{l}\text { Solid } \\
\text { tumours }\end{array}$ & I \\
\hline $\begin{array}{l}\text { C225-ILS- } \\
\text { Dox }\end{array}$ & EGFR & $\begin{array}{l}\text { Cetuximab } \\
\text { Fab }\end{array}$ & Lipid & Doxorubicin & $\begin{array}{l}\text { High-grade } \\
\text { gliomas }\end{array}$ & I \\
\hline MM-302 & HER2 & $\begin{array}{l}\text { Anti-HER } \\
\text { scFv }\end{array}$ & Lipid & Doxorubicin & $\begin{array}{l}\text { Breast } \\
\text { cancer }\end{array}$ & II \\
\hline MM-310 & $\begin{array}{l}\text { Ephrin receptor } \\
\text { A2 }\end{array}$ & $\begin{array}{l}\text { Anti-EphA2 } \\
\text { scFv }\end{array}$ & Lipid & Docetaxel & $\begin{array}{l}\text { Solid } \\
\text { tumours }\end{array}$ & I \\
\hline MCC-465 & $\begin{array}{l}\text { Uncharacterised } \\
(\mathrm{GAH})\end{array}$ & $\begin{array}{l}\text { Anti-GAH } \\
F\left(a b^{\prime}\right)_{2}\end{array}$ & Lipid & Doxorubicin & $\begin{array}{l}\text { Metastatic } \\
\text { stomach } \\
\text { cancer }\end{array}$ & I \\
\hline
\end{tabular}




\begin{tabular}{|c|c|c|c|c|c|c|}
\hline $\begin{array}{l}\text { Lipovaxin- } \\
\text { MM }\end{array}$ & $\begin{array}{l}\text { Dendritic cell } \\
\text { CD209 }\end{array}$ & $\mathrm{dAb}$ & Lipid & $\begin{array}{l}\text { Melanoma } \\
\text { antigens + } \\
\text { IFNy }\end{array}$ & Melanoma & 1 \\
\hline $\begin{array}{l}\text { Erbitux- } \\
\text { EDVspac }\end{array}$ & EGFR & $\begin{array}{l}\text { Bispecific } \\
\text { monoclonal } \\
\text { antibody } \\
(\mathrm{mAb})\end{array}$ & $\begin{array}{l}\text { Bacterially } \\
\text { derived } \\
\text { mini-cell }\end{array}$ & Paclitaxel & $\begin{array}{l}\text { Solid } \\
\text { tumours }\end{array}$ & II \\
\hline
\end{tabular}

\section{Conclusion}

The best way to use the targeting abilities of antibodies may never be agreed. ADCs have proven their ability to deliver cytotoxic payloads to tumours and are currently the most beneficial targeted, drug conjugated therapy for patients. ACNPs however may allow for existing chemotherapies to be made available in nanomedicinal preparations. Drug release from nanoparticles can be more finely controlled with a range of nanoparticle materials and co-excipients to choose from. ACNPs may provide benefit over ADCs when targeting receptors where receptor agonism can derive additional therapeutic effects. Furthermore, in this age of immunotherapy, the ability to use ACNPs to augment immune responses to tumours also hold much promise. With strategies to enhance the ability of these agents to reach tumours to facilitate active targeting, combined with improved uniform manufacturability from improved conjugation chemistries [55], it is anticipated that there will be an increase in the interest of these agents for clinical evaluation. 
Conflict of interest

Michael Johnston declares no conflict of interest

Christopher Scott is a consultant to Fusion Antibodies Ltd.

References

[1] Ehrlich P. Address in Pathology, on Chemotherapy: Delivered before the Seventeenth International Congress of Medicine. Br Med J 1913;2:353-9.

[2] Mathe G, Tran BA LOC, Bernard J. Effect on mouse leukemia 1210 of a combination by diazo-reaction of amethopterin and gamma-globulins from hamsters inoculated with such leukemia by heterografts. Comptes Rendus Hebd Des Séances l'Académie Des Sci 1958;246:1626-8.

[3] Ford CHJ, Newman CE, Johnson JR, Woodhouse CS, Reeder TA, Rowland GF, et al. Localisation and toxicity study of a vindesine-anti-CEA conjugate in patients with advanced cancer. vol. 47. 1983. doi:10.1038/bjc.1983.4.

[4] Tsuchikama K, An Z. Antibody-drug conjugates: recent advances in conjugation and linker chemistries. Protein Cell 2018;9:33-46. doi:10.1007/s13238-016-0323-0.

[5] Jia L. Nanoparticle Formulation Increases Oral Bioavailability of Poorly Soluble Drugs: Approaches Experimental Evidences and Theory. Curr Nanosci 2005;1:237-43. doi:10.2174/157341305774642939.

[6] Gunasekaran T, Haile T, Nigusse T, Dhanaraju MD. Nanotechnology: an effective tool for enhancing bioavailability and bioactivity of phytomedicine. Asian Pac J Trop Biomed 2014;4:S1-7. doi:10.12980/APJTB.4.2014C980.

[7] Zhang $\mathrm{H}$. Onivyde for the therapy of multiple solid tumors. Onco Targets Ther 2016;9:3001-7. doi:10.2147/OTT.S105587. 
[8] Saif MW. U.S. food and drug administration approves paclitaxel protein-bound particles (Abraxane $\left.{ }^{\circledR}\right)$ in combination with gemcitabine as first-line treatment of patients with metastatic pancreatic cancer. J Pancreas 2013;14:686-8.

[9] Gabizon A, Catane R, Uziely B, Kaufman B, Safra T, Cohen R, et al. Prolonged Circulation Time and Enhanced Accumulation in Malignant Exudates of Doxorubicin Encapsulated in Polyethylene-glycol Coated Liposomes 1. vol. 154. 1994.

[10] Heath TD, Fraley RT, Papahdjopoulos D. Antibody targeting of liposomes: cell specificity obtained by conjugation of $F(a b ') 2$ to vesicle surface. Science 1980;210:539-41. doi:10.1126/SCIENCE.7423203.

[11] Leserman LD, Barbet J, Kourilsky F, Weinstein JN. Targeting to cells of fluorescent liposomes covalently coupled with monoclonal antibody or protein A. Nature 1980;288:602-4.

[12] Shi J, Kantoff PW, Wooster R, Farokhzad OC. Cancer nanomedicine: progress, challenges and opportunities. Nat Rev Cancer 2017;17:20-37. doi:10.1038/nrc.2016.108.

[13] Mamot C, Ritschard R, Wicki A, Stehle G, Dieterle T, Bubendorf L, et al. Tolerability, safety, pharmacokinetics, and efficacy of doxorubicin-loaded anti-EGFR immunoliposomes in advanced solid tumours: a phase 1 dose-escalation study. Lancet Oncol 2012;13:1234-41. doi:10.1016/S1470-2045(12)70476-X.

[14] Miller K, Cortes J, Hurvitz SA, Krop IE, Tripathy D, Verma S, et al. HERMIONE: a randomized Phase 2 trial of MM-302 plus trastuzumab versus chemotherapy of physician's choice plus trastuzumab in patients with previously treated, anthracyclinenaïve, HER2-positive, locally advanced/metastatic breast cancer. BMC Cancer 2016;16:352. doi:10.1186/s12885-016-2385-z.

[15] Sharma A, Sharma US. Liposomes in drug delivery: Progress and limitations. vol. 
154. 1997. doi:10.1016/S0378-5173(97)00135-X.

[16] Fay F, Scott CJ. Antibody-targeted nanoparticles for cancer therapy. Immunotherapy $2011 ; 3: 381-94$.

[17] Schmid D, Jarvis GE, Fay F, Small DM, Greene MK, Majkut J, et al. Nanoencapsulation of ABT-737 and camptothecin enhances their clinical potential through synergistic antitumor effects and reduction of systemic toxicity. Cell Death Dis 2014;5:e1454. doi:10.1038/cddis.2014.413.

[18] Uadia P, Blair AH, Ghose T. Tumor and tissue distribution of a methotrexate-anti-EL4 immunoglobulin conjugate in EL4 lymphoma-bearing mice. Cancer Res 1984;44:4263-6.

[19] Laguzza BC, Nichols CL, Briggs SL, Cullinan GJ, Johnson DA, Starling JJ, et al. New antitumor monoclonal antibody-vinca conjugates LY203725 and related compounds: design, preparation, and representative in vivo activity. J Med Chem 1989;32:548-55. doi:10.1021/jm00123a007.

[20] Trail PA, Willner D, Lasch SJ, Henderson AJ, Hofstead S, Casazza AM, et al. Cure of xenografted human carcinomas by BR96-doxorubicin immunoconjugates. Science $1993 ; 261: 212-5$.

[21] Chari RVJ, Miller ML, Widdison WC. Antibody-Drug Conjugates: An Emerging Concept in Cancer Therapy. Angew Chemie Int Ed 2014;53:3796-827. doi:10.1002/anie.201307628.

[22] Lambert JM. Antibody-drug conjugates: Targeted delivery and future prospects. Ther Deliv 2016;7:279-82. doi:10.4155/tde-2016-0010.

[23] Chitkara D, Kumar N. BSA-PLGA-based core-shell nanoparticles as carrier system for water-soluble drugs. Pharm Res 2013;30:2396-409. doi:10.1007/s11095-013-1084-6.

[24] Sochaj AM, Świderska KW, Otlewski J. Current methods for the synthesis of 
homogeneous antibody-drug conjugates. Biotechnol Adv 2015;33:775-84.

doi:10.1016/j.biotechadv.2015.05.001.

[25] Hamblett KJ, Senter PD, Chace DF, Sun MMC, Lenox J, Cerveny CG, et al. Effects of drug loading on the antitumor activity of a monoclonal antibody drug conjugate. Clin Cancer Res 2004;10:7063-70. doi:10.1158/1078-0432.CCR-04-0789.

[26] Wang L, Amphlett G, Blättler WA, Lambert JM, Zhang W. Structural characterization of the maytansinoid-monoclonal antibody immunoconjugate, huN901-DM1, by mass spectrometry. Protein Sci 2005;14:2436-46. doi:10.1110/ps.051478705.

[27] Senter PD, Sievers EL. The discovery and development of brentuximab vedotin for use in relapsed Hodgkin lymphoma and systemic anaplastic large cell lymphoma. Nat Biotechnol 2012;30:631-7. doi:10.1038/nbt.2289.

[28] Gao H, Yang Z, Zhang S, Cao S, Shen S, Pang Z, et al. Ligand modified nanoparticles increases cell uptake, alters endocytosis and elevates glioma distribution and internalization. Sci Rep 2013;3. doi:10.1038/srep02534.

[29] Lu J, Jiang F, Lu A, Zhang G. Linkers having a crucial role in antibody-drug conjugates. Int J Mol Sci 2016;17. doi:10.3390/ijms17040561.

[30] Ashton S, Song YH, Nolan J, Cadogan E, Murray J, Odedra R, et al. Aurora kinase inhibitor nanoparticles target tumors with favorable therapeutic index in vivo. Sci Transl Med 2016;8:325ra17-325ra17. doi:10.1126/scitranslmed.aad2355.

[31] Huet HA, Growney JD, Johnson JA, Li J, Bilic S, Ostrom L, et al. Multivalent nanobodies targeting death receptor 5 elicit superior tumor cell killing through efficient caspase induction. MAbs 2014;6:1560-70. doi:10.4161/19420862.2014.975099.

[32] Perica K, Tu A, Richter A, Bieler JG, Edidin M, Schneck JP. Magnetic Field-Induced T Cell Receptor Clustering by Nanoparticles Enhances T Cell Activation and Stimulates Antitumor Activity. ACS Nano 2014;8:2252-60. doi:10.1021/nn405520d. 
[33] Bray D, Levin MD, Morton-Firth CJ. Receptor clustering as a cellular mechanism to control sensitivity. Nature 1998;393:85-8. doi:10.1038/30012.

[34] Caré BR, Soula HA. Impact of receptor clustering on ligand binding. BMC Syst Biol 2011;5:48. doi:10.1186/1752-0509-5-48.

[35] Kindler HL, Richards DA, Garbo LE, Garon EB, Stephenson JJ, Rocha-Lima CM, et al. A randomized, placebo-controlled phase 2 study of ganitumab (AMG 479) or conatumumab (AMG 655) in combination with gemcitabine in patients with metastatic pancreatic cancer. Ann Oncol 2012;23:2834-42. doi:10.1093/annonc/mds142.

[36] Pan Y, Haddad V, Sabin T, Baker N, Hei YJ, Galimi F, et al. Predictive value of Fc gamma receptor Illa genotype in response to conatumumab in three phase II studies. J Clin Oncol 2011;29:3103-3103. doi:10.1200/jco.2011.29.15_suppl.3103.

[37] Li F, Ravetch J V. Apoptotic and antitumor activity of death receptor antibodies require inhibitory Fcy receptor engagement. Proc Natl Acad Sci U S A 2012;109:10966-71. doi:10.1073/pnas.1208698109.

[38] Schmid D, Fay F, Small DM, Jaworski J, Riley JS, Tegazzini D, et al. Efficient Drug Delivery and Induction of Apoptosis in Colorectal Tumors Using a Death Receptor 5Targeted Nanomedicine. Mol Ther 2014;22:2083-92. doi:10.1038/mt.2014.137.

[39] Spence S, Greene MK, Fay F, Hams E, Saunders SP, Hamid U, et al. Targeting Siglecs with a sialic acid-decorated nanoparticle abrogates inflammation. Sci TransI Med 2015;7:303ra140. doi:10.1126/scitransImed.aab3459.

[40] Brunker P, Wartha K, Friess T, Grau-Richards S, Waldhauer I, Koller CF, et al. RG7386, a Novel Tetravalent FAP-DR5 Antibody, Effectively Triggers FAPDependent, Avidity-Driven DR5 Hyperclustering and Tumor Cell Apoptosis. Mol Cancer Ther 2016;15:946-57. doi:10.1158/1535-7163.MCT-15-0647.

[41] Cruz LJ, Tacken PJ, Pots JM, Torensma R, Buschow SI, Figdor CG. Comparison of 
antibodies and carbohydrates to target vaccines to human dendritic cells via DCSIGN. Biomaterials 2012;33:4229-39. doi:10.1016/J.BIOMATERIALS.2012.02.036.

[42] Manolova V, Flace A, Bauer M, Schwarz K, Saudan P, Bachmann MF. Nanoparticles target distinct dendritic cell populations according to their size. Eur J Immunol 2008;38:1404-13. doi:10.1002/eji.200737984.

[43] Paulis LE, Mandal S, Kreutz M, Figdor CG. Dendritic cell-based nanovaccines for cancer immunotherapy. Curr Opin Immunol 2013;25:389-95. doi:10.1016/j.coi.2013.03.001.

[44] Rosalia RA, Cruz LJ, van Duikeren S, Tromp AT, Silva AL, Jiskoot W, et al. CD40targeted dendritic cell delivery of PLGA-nanoparticle vaccines induce potent antitumor responses. Biomaterials 2015;40:88-97. doi:10.1016/j.biomaterials.2014.10.053.

[45] Gargett T, Nazim Abbas · M, Rolan · Paul, Price JD, Gosling KM, Ferrante · Antonio, et al. Phase I trial of Lipovaxin-MM, a novel dendritic cell-targeted liposomal vaccine for malignant melanoma 2018;67:1461-72. doi:10.1007/s00262-018-2207-z.

[46] Schmid D, Park CG, Hartl CA, Subedi N, Cartwright AN, Puerto RB, et al. T celltargeting nanoparticles focus delivery of immunotherapy to improve antitumor immunity. Nat Commun 2017;8:1747. doi:10.1038/s41467-017-01830-8.

[47] Wilhelm S, Tavares AJ, Dai Q, Ohta S, Audet J, Dvorak HF, et al. Analysis of nanoparticle delivery to tumours. Nat Rev Mater 2016;1:16014. doi:10.1038/natrevmats.2016.14.

[48] Miller MA, Gadde S, Pfirschke C, Engblom C, Melissa M, Kohler RH, et al. Predicting therapeutic nanoparticle efficacy using a companion MR imaging nanoparticle. Sci Transl Med 2015;7:314ra183. doi:10.1126/scitransImed.aac6522.Predicting.

[49] Lu D, Wientjes MG, Lu Z, Au JL-S. Tumor priming enhances delivery and efficacy of 
nanomedicines. J Pharmacol Exp Ther 2007;322:80-8. doi:10.1124/jpet.107.121632.

[50] Hylander BL, Sen A, Beachy SH, Pitoniak R, Ullas S, Gibbs JF, et al. Tumor priming by Apo2L/TRAIL reduces interstitial fluid pressure and enhances efficacy of liposomal gemcitabine in a patient derived xenograft tumor model. J Control Release 2015;217:160-9. doi:10.1016/j.jconrel.2015.08.047.

[51] Perez HL, Cardarelli PM, Deshpande S, Gangwar S, Schroeder GM, Vite GD, et al. Antibody-drug conjugates: current status and future directions. Drug Discov Today 2014;19:869-81. doi:10.1016/j.drudis.2013.11.004.

[52] Kunert R, Reinhart D. Advances in recombinant antibody manufacturing. Appl Microbiol Biotechnol 2016;100:3451-61. doi:10.1007/s00253-016-7388-9.

[53] Richards DA, Maruani A, Chudasama V. Antibody fragments as nanoparticle targeting ligands: a step in the right direction. Chem Sci 2016;8:63-77. doi:10.1039/c6sc02403c.

[54] van der Meel R, Vehmeijer LJC, Kok RJ, Storm G, van Gaal EVB. Ligand-targeted particulate nanomedicines undergoing clinical evaluation: Current status. Adv Drug Deliv Rev 2013;65:1284-98. doi:10.1016/j.addr.2013.08.012.

[55] Greene MK, Richards DA, Ao J, Nogueira CF, Campbell K, Smyth P, et al. Forming next-generation antibody-nanoparticle conjugates through the oriented installation of non-engineered antibody fragments † 2018. doi:10.1039/c7sc02747h. 